\title{
Role of banking sector in promoting green investments: Exploring new developments
}

\author{
Wijethunga A.W.G.C.N \& Dayaratne D.A.I \\ Department of Accountancy\& Finance, Faculty of Management Studies, \\ Sabaragamuwa University of Sri Lanka
}

\begin{abstract}
The corporate landscape is gradually moving towards a new premise in the wake of emerging climate change issues encountered by the business community. The natural disasters which experience globally due to climate change have the disruptive effect on corporate sustainability in long run as well as short run profitability of the corporate sector. It is generally believed that the banking sector has a primary responsibility for the go green and should take their hand together in green economic growth. Thus, this paper emphasizes on the role of banking sector in green growth in developing country of Sri Lanka based on secondary data like journals, paper articles, bank reports etc. Currently, Sri Lankan banking sector has taken their initial initiatives to improve the banking sector through green banking activities which are ultimately beneficial to the country's sustainable growth. Green Banking is a not an individual task of banks multi -stakeholders attempt is needed to enhance desired green growth.
\end{abstract}

Keywords: Green Investments, Banking Sector, Green Growth, Developing Context

\section{Introduction}

The process of collecting excess funds from financial surplus units and redistributing collected funds among financially deficit unit is the major role of the banks in the financial system. Moreover, as a financial intermediary in the financial system banks facilitate to fill the saving and investment gap in the economy and ultimately it will lead to enhance economic growth. All business organizations in the economy are inspired by the profit maximization motive and similarly, banks are also motivated by profit maximization objective through lending process and other banking and non-banking activities, mainly financial intermediary services. It is learnt that during past few centuries, banks driven by profit orientation motive due to the unsustainable economic development consideration and consensus in the world economy. However, in the $21^{\text {st }}$ century, the banking sector has interconnected to the part of the sustainable development taking into account the social and economic aspects other than the profit maximization motive of its operations. Under sustainable development concept, present considerations of green economic activities are focused that do not destroy the planet in order to maximize the organizational profit. As a logical initiative, at the beginning of $21^{\text {st }}$ century, green 
banking concept was emerged to protect the environment and reduce carbon emissions by introducing green banking practices.

Moreover, now the global leaders have taken the subject of climate change issues in all most all global summits and conferences and timely important measures are being implemented. For an example, Paris agreement is the one of the significant landmarks taken by the world economies for battling against climate change. It takes a great effort to limit the temperature increase to 1.5 degrees Celsius. Advocates of climate change issues claim that the catastrophes are manmade which induces the corporate managers to concern about the environmental standard and guidelines and compliance with the law enactments in corporate decisions. In complying with the new developments in the world, recently international banking organizations made significant changes to reform banking operations to enhance sustainability through environmental friendly manner. As an example, the International Finance Corporation (IFC) has formed Sustainable Banking Network (SBN) to promote green financing through the banking sector. Under this initiative, the banks will also be encouraged to provide financial facilities to green enterprises with the intention of protecting the planet for the future generation. The Sustainable Banking Network (SBN) of the IFC is a knowledge and capacity building platform for financial regulators and banking associations of emerging markets on sustainable finance ${ }^{1}$.
Further it highlighted that, 13 Asian countries out of the 32 countries adopted the SBN which is important to knowledge disseminating among banking regulators and banking associations established in 2012. It supports the improvement of environmental and social risk management of financial institutions and promotes green and inclusive lending process. ${ }^{2}$ The encouraging steps of Central Bank of Sri Lanka also induces the banks to adopt the sustainable banking practices and to help the banks to effectively manage environmental and social risks in the projects they finance and support businesses that are greener, climate friendly and socially inclusive.

According to Thombre (2011) the green banking is operating like a normal bank, which considers all the social and ecological factors with an aim to protect the environment. Therefore, it serves both the profit-making objective of the bank as well as its social responsibility role on the entire economy as a socially responsible establishment. Further, Rajesh \& Dileep (2014) defined that green banking refers to the efforts of the banking sector to keep the environment green and to minimize greenhouse effects through in-house operational activities and green finance motives. Accordingly, the transformation of the internal banking operation into a green oriented operation mechanism refers to greening the in-house operational activities like online banking, mobile banking, e-pass books, e-bank statements, ATMs, SMS 
banking etc. and accountability of financial resource allocation on green investments. Green finance defines as financial support for the green growth of the economy which aims to reduce greenhouse gases and air pollutant emissions significantly. Moreover, in establishing the green banking system, both financial assets and fixed assets of the banking companies are used to enhance own sustainability, stakeholders' sustainability and the economic sustainability.

In many developing countries, accountability is lacking, irresponsibility is general phenomena, high level of corruptions in the political system and misuse of the public resources due to the drawbacks of governance mechanism. On the other hand, the high population growth in developing countries is generating an extraordinary rise in demand for energy, water, transport, urban development and agricultural infrastructure. When they are fulfilling the growing demand, the global environmental and sustainability obligations will be challenging largely. Obviously, these issues promote unfavorable setting and major constraint in turning the economy into the green growth economy. Thus, arguably, the all stakeholders in the economy have countless accountability to protect the society and refrain from distorting the surrounding by substantial amounts of investment in the water, agriculture, power, transport, buildings, and industrial and forestry sectors to ensure a conducive living space for the future generation. As an important stakeholder of the economy, banks also have primary responsibility for preserving green environment through green financing policies and practices. On the other hand, as a socially responsible unit in the society, the banks should inspire the financing in ecological infrastructure such as renewable energy project, clean water supply project, wastewater treatment plant, solid \& hazardous waste disposal plant, bio-fertilizer plant based on under the mode of investment. Moreover, banks have to assess their environmental risks for financing in different sectors in different areas for creating a fund like Climate Change Risk Fund. If the banking sector fails to perform their prime social responsibility as well as green financing concepts, the society and economic development would be significantly affected and no one can save from the mounting distress. Green financing related products and services have to be made in the best interest of all concerned parties. The study has a pronounced academic value as it is an eye opener for the policy makers and also this is an emerging area of research which needs substantive objective oriented scientific evidences. Thus, this study aims to achieve several objectives such as (a) to study various strategies for green banking approach (b) to explore the various initiatives taken peruse green banking and environment sustainability by banks (c) to study the major challenges for green banking and green finance initiatives. 


\section{Emerging demand for green banking}

The business valuation is moving to a new platform due to the pressure of climate change and global temperature increase. About decades ago the global risk in terms of impact and likelihood did not include social and environmental issues. However, today four of the five business risks are social or environmental driven by extreme weather events, water crises, and natural disasters. ${ }^{3}$ Now more often than not business analysts should account for new risk factors in business decisions. In future, the companies in their operations need to connect with the sustainable development goals which require tremendous changes to the organizations which agreed upon by all the 193 in the world. Sri Lanka is one of the signatories to this agreement. The critical issue is that most of developing countries are most vulnerable to climate changes due to less tolerability. It is now proven fact that ecological deteriorating problem like air pollution and the shortage of natural resources, deforestation, increasing disaster risk and loss of biodiversity more often reported phenomenon now. This requires, all stakeholders in the world have prime responsibility to be mindful about environmental degradation and its impact on the livelihood people in generation to come. Financial sector also an important stakeholder in the economy and it plays a critical role in economic development. The financial sector directly influence on the corporate sector as well as external sector of an economy. Therefore, it is vividly important to take green initiatives by the banking sector to sustain the selfsustainability and the sustainability of other economic agents. This will lead to sustain the performance of the banking sector and as well as directly impact on economic sustainability.

\section{Literature review}

Apart from the risk factors that effect on the financial institutions the Financial Stability Board of G20 identifies that there are three climate risks which are faced by the financial institutions in the economy. They are namely, physical risk, liability risk and transition risk. ${ }^{4}$ Further elaborating them, the physical risk refers to the risk which financial institution has to bear due to climate change events such as floods and storms that damage property or interrupt trade. Liability risk of climate change occurs when and if parties who have suffered loss or damage from the effects of climate change seek compensation from those they hold responsible. In the modern economy, financial institutions, whether voluntarily or involuntarily have to reform their whole operating process into eco-friendly operating process. On the other hand, transition of financial risk results from the process of adjusting toward ecofriendly process. The change in policy and technology are needed to adjust the traditional operating process to ecological operational flat form.

Furthermore, Katyal \& Nagpal (2014) contend that in addition to the above 
climate risks, normal banking institutions have to bear credit risk, legal risk and reputational risk due to traditional banking practices in the sustainable motive economy. The primary activity of a bank is lending. When banks lend funds to business firms whose businesses are harmful to the environment and those businesses can be categorized as harmful businesses to the environment. Those companies have the risk of lawsuit by the regulators and this will increase the credit risk of the banks. Banks are one component of the financial systems of a country and they have to comply with the all legal requirements which are implemented by the governing bodies from time to time. In this perspective, banks are at a legal risk if they themselves do not operate in conformity with the environmental regulations and other operational matters enforced by the authorities. On the other hand, more than risk comes from inadequate environmental practices of projects funded by the banks the legal risk can be some devastating impact on the banks. Bankers lose their goodwill and face reputation risk if they involve in big projects which adversely affect on the environment and causes pollution. Therefore, to mitigate the risk arise from those sources and adaptation of green policy for bank operation is a conservative policy for the future sustainability of banks and economic development.

The green banking concept is not a newly evolved practice and it was first established in 1980 at Triodos bank from Dutch origin which started the environmental sustainability in the banking sector from the very first day. After, three decades since then, scholars have attempted to study the concept of green banking by linking the concept with the economic sustainability. For example, Ginovsky (2009) suggested that traditional banks should launch new banking products which encourage sustainable practices and also needs to reform their in-house operations in order to implement environmentally friendly practices. Moreover, Ginovsky (2009) highlighted that use of paperless banking is essentially important to reduce the carbon footprint from internal banking operations and it is a cost saving mechanism to banks, which adopt Green Street lending, which refers offering low price (rate of interest) to consumers and businesses for installing solar energy systems and energy-saving equipment.

Moreover, Katyal \& Nagpal (2014) identified that carbon credit business, green banking financial products, paperless banking, energy consciousness, green buildings and plantation as strategies which are also hallmarks to adopt the banking operations to enhance sustainable banking practices in a country. Interestingly, green banking initiatives and practices of a bank will be beneficial not only for the green environment but also lead to cost reductions in banking related activities. (Jayadatta \& Nitin, 2017). Moreover, green banking 
increases the return on green investment and reduces the investment risk and cost of private capital into green projects by leveraging the economies of scale. Similarly, Hart \& Ahuja (1996) revealed a positive correlation between environmental performance and financial performance.

Furthermore, Sreesha (2014) compared that the green banking adoptability of public sector banks and private sector banks in the India and noted that public sector banks more concern in green banking as compared to private sector banks. Therefore, Sreesha (2014) disclosed that maintaining the sustainability in a bank, the bank should enlarge the use of environmental information in the banking operation, lending and investment decisions. It will be useful for the banking industry to improve sustainability of environment and to generate a long term value for the banking companies.

Green practices of banks generate numerous benefits and advantages for the society and economy. Those are; (a) basically, green banking avoids paper work as the bank transactions are carried out over online banking system, (b) making awareness to business people about environmental and social responsibility enabling them to do an environmental friendly business practices, (c) banks follow environmental standards for lending, which is really an excellent idea and it will make business owners to change their business to environmentally friendly which is good for future generations . (Ragupathi \&
Sujatha, 2015) In Sri Lankan context, Shaumya \& Arulrajah (2017) revealed green bank practices positively impact toward the bank's environmental performance resulting the employee related practices, daily operation related practices and bank's policy related practices. Moreover, they identified that all stakeholders' involvement is essential in several areas such as the green banking and employee related practices, daily operation related practices, customer related practices and bank's policy related practices are the important aspect of green banking.

\section{Benefits of green banking adaptation}

Generally, green banking practices bring several benefits to the bank itself as well as customers of the bank and the entire economy through the environmental benefits. Green banking practices play a major role in reducing bank's internal operating cost and ultimately it will positively impact on the financial performance of the bank. (Heim \& Zenklusen, 2005) In the modern context, green banking practices are usually combined with the technology advancement and it lead to lower the cost of operation of the banks. Moreover, technology based green banking practices are essential to expand the market share of the bank. Other than that, in bank perspective, it will increase the speed of banking services which is important to enhance the overall efficiency of the bank . Du (2011) In addition, Deka (2015) noted that green banking practices will generate benefits to the bank by 
improving bank image, energy saving, cost effectiveness, better customer service, quick $\&$ convenient, Increase profits, boundary less network. Similarly, Deka (2015) noted that green bank adoptions of banks are very convenient, time saving and easy to customers of the bank because customers need not go to the bank premises for banking transactions due to most common green banking practices like ATMs, credit cards, debit card, mobile banking, e-banking, etc.

In general, green banking benefits toward economic sustainability by contributing to protecting the environment in several ways. For example, banks provide loans to their customers at concessional rates for the environment friendly products and projects which ultimately contribute to reduce carbon emission and maintain the ecological balance in the atmosphere. Also, paperless banking activities also contribute to reducing deforestation. Moreover, when banks follow environmental standards for loaning process, is truly a good initiative and it will induce entrepreneurs to transform their business operations to environmental friendly manner. On the other than, the banking industry can significantly contribute to maintain ecological balance of the world by adopting green practices in the operations.

\section{Green banking for sustainability}

The conventional banking system is a profit oriented system which focuses on cost minimization and profit maximization objectives. Moreover, conventional banking system concentrated on their financial stability, operational efficiency, institutional profits, economic benefits and organizational benefits. However, green banking system expands their focus beyond the profit and it considers the protection of planet for the future generation. Therefore, green banking system follows financial and social stability, ethical human and social commitment, community profit, allocation efficiency and social benefits. It is witnessed that Green bank plays the roles of an ecologist, preservationist, non-polluter and a generator of the natural environment. Moreover, a bank performs the role of an environmental auditor, to evaluate the environmental impact of in-house business activities as well as external business projects and activities through the resource allocation process.

It is learnt that Green Banking should be focused on two approaches; all banks have to transform their in-house operation into green concept and environmentally responsible finance meaning that finance on ecologically friendly projects \& activities. Ultimately, it will be useful to achieve sustainability of the bank leading to economic sustainability. Green trans formation of the in-house operation of the banks can be executed in different ways such as (a) online operations. It saves forest coverage of the world as saving of huge waste of papers. Moreover, it also helps customers to save money by avoiding late payments and save their time; (b) uses of green checking accounts and green credit 
cards. Green checking accounts help customers to check their accounts through ATMs. Green credit cards allow donating funds to an environment friendly non-profit organization all over the world; (c) green buildings for bank premises; (d) mobile banking and online banking etc. Other than the in-house, green banking practices the banks provide funds for ecological activities by sponsoring CSR activities and lending on ecological projects and agricultural sector at concessional interest rates. Moreover, the most important component of green banking is engaging with key stakeholders of the system and creating awareness of environmental issues and their impact on the economy, the environment, and the society. Most importantly, banks have to educate all stakeholders regarding the business and environmental value and impact of greening the bank processes and available green banking products and services available in the banks. Green bank adaptations in the banking sector result for the bank selfsustainability by touching beyond the profit policy. Ultimately it will contribute to economic sustainability. This process is shown in the following conceptual map.

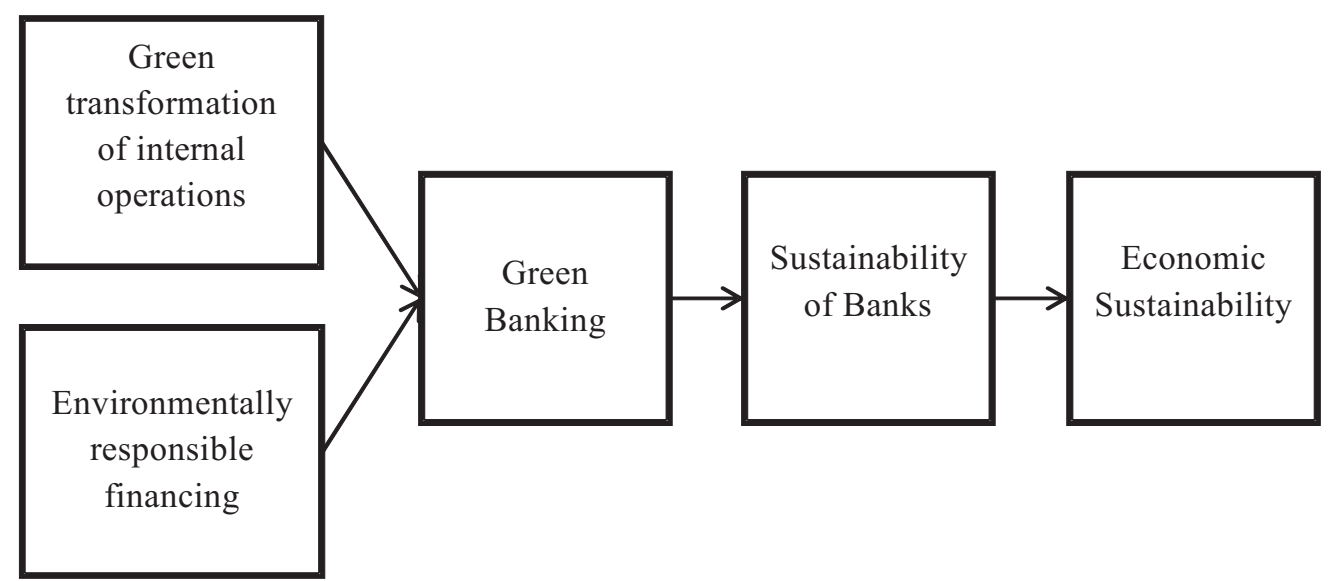

Figure 1: Conceptual map

\section{Global experiences in green banking}

In the mid of the 1990s, the United Nation Environment Programme (UNEP) announced the UNEP Finance Initiative (UNEPFI) which aims to incorporate the ecological and social dimensions into the assessment of financial performance and risk that relates with the financial industry. Following this initiative, 34 international banks adopted the codes of conduct of the UNEP relative to the environmental reporting, environmental management system, environmental policies and environmental risk assessment to reduce environmental impact both internally and externally. Afterwards, in 2002, a global alliance of Non-governmental organizations formed a mechanism which is called "Bank Tract" to promote sustainable 
finance in the corporate sector aligning with banking industry focusing on six dimensions of (a) responsibility; (b) accountability; (c) transparency; (d) sustainable market; (e) sustainability (f) no-harm and governance. Most of the banks together with International Finance Corporation set up to start the process of preparation the common guidelines in October 2002 and finally concluded the guidelines in June 2003 recognized as "Equator Principles" and finally it has considered as a benchmark of project finance that incorporates environmental social issues of financing projects.

Later, Congressman Chris Van Hollen has taken formalities to introduce a green bank Act in 2009 in view of targeting the formation of Green Bank under the ownership of government of the United States government with the purposes of offering financial sustenance to efforts to increase energy usage efficiency, to decrease carbon emissions and other environmental pollution resulting from energy creation. However, many economics adopted green banking initiatives in different ways. A developing country context of China, in 2007, the People's Bank of China (PBOC), China Banking Regulatory Commission (CBRC), and Ministry of Environmental Protection collaboratively designed the "Green Credit Policy" and adopted it to the banking system and China Banking Regulatory Commission used it as a monitoring framework. According to the green credit statistics of major 21 Chinese banks showed that the volume of Chinese banks' green credit portfolio has grown steadily during the period of 2013 to 2017. The green credit landings of major 21 banks have grown from 5.20 trillion to 8.30 trillion showing that green credit approximately $10 \%$ of these banks' credit portfolios. Moreover, within the period of 2013 to 2017 12 types of energy saving and environmental protection loans lending have saved 215 million tons of standard coal, reduced 491 million tons of carbon dioxide equivalent emission, 0.27 million tons of ammonia nitrogen, 4.65 million tons of $\mathrm{SO} 2,3.13$ million tons of Oxides of Nitrogen (NOx), and saved 715 million tons of water wastage. $^{5}$

Another emerging industrialized economy of Brazil also adopted greening of the banking practices in several ways to enhance sustainability. In 2005, five Brazilian state-owned banks adopted voluntary green protocols which are called as FEBRABAN facilitated by the Banking Association of Brazil. Later in 2009, all commercial banks adopted the voluntary green protocol. In 2014, mandatory resolution on Social and Environmental Responsibility for Financial Institutions is published by the Central Bank of Brazil and all financial institutions are liable to adopt it. Approximately $12 \%$ of banks' loans and advances granted to new energy projects as well as the low carbon agricultural products. For more than two decades, India also 
applies green banking concept to their financial sector. Mainly, Indian banks implemented loan programmes for women and economic development projects. In 2010, the State Bank of India (SBI) has executed the Green Channel Counter (GCC) in more than 5,000 branches around India to promote paperless transactions.

A developing Asian country of Bangladesh implemented green practices in banking sector to increase energy usage efficiency, and thereby to reduce carbon emissions and other environmental pollution resulting from energy creation, reducing the country's dependence on foreign energy sources, fighting against climate change and creating new job opportunities through energy generation facilities. Bangladesh banks applied green strategic planning from 2013. However, Bangladesh banks started their green banking policy from 2011 which includes three phases. At the first stage, policy formation and governance, incorporation of environmental risk in core risk management, initiating in-house environment management, introducing green finance, the creation of climate risk fund, introducing green marketing, online banking and reporting green bank practices was target. The second phase was introduced in $31^{\text {st }}$ December 2012 and it focused on sector specific environmental policy, green strategic planning, setting up of green banking, improve in-house environment management, formulation of bank specific environmental risk management plan and guideline, rigorous programmes to educate clients and disclose green banking activities. As the last phase, they were focused on designing and introducing new products. Finally, they achieved considerable progress in green banking hitting a total of 45 banks which have formulated green banking practices. Importantly, 22 branches and 150 SME units powered by solar energy, 37 banks are fully automated, 3226 branches have been facilitated by Online Coverage, Increasing Climate Change fund and Bangladesh Climate Change resilience fund, Taka 835.4 Million taka spent from Bangladesh Banks for green banking initiatives.

Bangladesh bank has taken several initiatives to spread green banking practices into the Bangladesh banking sector and the progress reports a significant improvement. The Figure 2 shows their direct and indirect green finance investment in the banking industry over the period of 2011 to 2016 . Furthermore, Indonesia developed a roadmap for sustainable finance in 2014, called as detailed work plan on the sustainable finance program for the financial service industry including green lending models for priority sectors in Indonesian economy. 


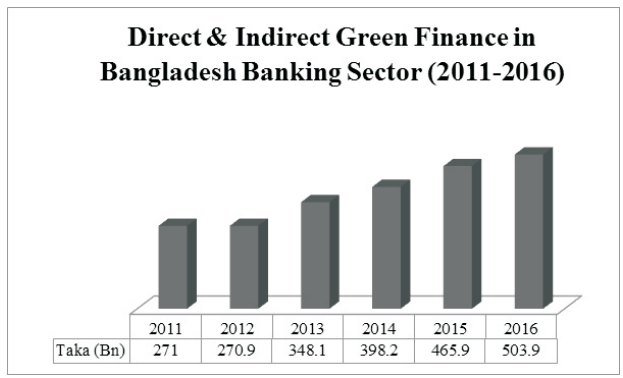

Source: Annual Reports of Bangladesh Bank.

Figure 2: Direct \& indirect finance in Bangladesh banking sector over the period from 2011 to 2016.

Similarly, a developed industrialized country of Japan adopted green banking initiatives aiming to minimize the adverse ecological impact of projects. The Development Bank of Japan has commenced eco-rating and low interest lending for ecological innovations as well as for developing a high level environment management system. ${ }^{6}$ Last eight years Development Bank of Japan has supported diverse B2B companies for promoting their environmental activities. Interestingly, Germany established their entire economic policy, targeting to reduce greenhouse gas emission by $55 \%$ by 2030 . In order to achieve desired target, Germany transformed their banking sector to ecological sector by implementing several initiatives. In 2015, German banks' Social Responsibility Investment (SRI) reported 136.6 billion Euros with a $10 \%$ yearly growth. ${ }^{7}$

\section{Green initiatives by Sri Lankan commercial banks}

As an initiative to the green banking concept
Sri Lanka Banks' Association (SLBA) took the upper hand for initiating Sri Lanka sustainable bank initiatives supported by European DFIs in 2015. On $5^{\text {th }}$ November 2015, 18 commercial banks operating in Sri Lanka gave their consent to a document containing 11 Sustainable Banking Principles (SBPs) for Sri Lanka to contribute to the sustainable development goals. ${ }^{8}$ Those banks are: Amana Bank, Cargills Bank, Commercial Bank of Ceylon, DFCC Bank, Habib Bank, Hatton National Bank, MCB Bank, National Development Bank, Nations Trust Bank, Pan Asia Bank, Peoples Bank, Regional Development Bank, Sampath Bank, Sanasa Development Bank, Seylan Bank, Sri Lanka Savings Bank and Union Bank. Moreover, the 4 sustainable banking principles (Business activities for environmental and social risk management, business operations for minimize environmental and social footprint, Environmental and Social (E\&S) risk governance and promote green economy growth) directly linked with green activities. Through this collective task they are trying to integrate environmental and social considerations into decision-making processes relating to banking activities to evade, minimize or offset negative impacts of decisions, minimize the negative impact of bank operations on the environment and local communities in which they operate and, where possible, promote positive impacts and promote green growth of the country through promoting projects other 
activities that contribute to achieve a green and clean economy in Sri Lanka.

Further, the Bank of Ceylon, as a largest public bank in Sri Lanka, with the best practices that came up with the digital transformation the banking system was able to move into a green banking process in dayto-day bank operations, especially, paper work was reduced through technology adaptation to bank operation system. With these initiatives, Bank of Ceylon has minimized waste and carbon emission to a greater extent. During the past three years, Bank of Ceylon was capable in recycling 389,440 kilograms of paper that was calculated to save 6621 fully-grown trees. ${ }^{9}$

Moreover, Smart Products such as 'SmartGen" were introduced substitute conventional savings accounts that use passbooks where there was a lot of paper usage. Other than that, Smart Zones were introduced for 24 hours paperless transactions in seven days. Bank has adopted a comprehensive Document Management System (DMS) in the internal environment and E-learning facility for employee training as well.

On the other hand, one of the leading private commercial banks in Sri Lanka is Commercial Bank of Ceylon and the bank has already been exposed to green banking practices. ${ }^{10}$ The Bank applied the criteria of the Banks Social and Environmental Management System (SEMS) to all credit proposals and their own bank activities. Moreover, they upgraded procurement practices and policies for reduction of energy use and minimize waste and procurement of ATMs and IT equipment that have Energy Star 5 ratings and are compliant with the Restriction of Hazardous Substances Directive (RoHS) standards. Furthermore, Commercial Bank of Ceylon invested in energy-efficient lighting and air conditioning equipment, conserving energy over the long term. When considering their operations, they have designed new branches to use more natural lightings. For example, Commercial Bank of Ceylon has already generated $40 \mathrm{~kW}$ of solar power for its four branches. They protect the environment by reducing the carbon footprint through migration to eStatements, Document Workflow and Soft Copy and electronic banking channels. ${ }^{11}$

Moreover, Hatton National Bank (HNB) engaged in the going green concept and HNB engaged on a 1.3 megawatt solar power project to carry out its processes in an environmentally sustainable manner. This project expects to generate two million kilowatt-hours of power per annum, which enables HNB to cover $15 \%$ of its total power needs through solar energy which in turn reduces the carbon footprint of the bank by 850 metric tons. ${ }^{12}$ Also, HNB progressed towards implementation of an Environmental and Social Management System (ESMS) for their lending decision making. HNB follows a policy called as $3 R$ policy - Reduce, Reuse and Recycle towards all tangible resources to protect the environment. They adopt scorecards and 
rating systems to assess the environmental and social impact of the lending activity. As similar to the Commercial bank of Ceylon, HNB largely follows green procurement system.

Further expanding this concept in the net work of banks in Sri Lanka, the Sampath bank PLC also joined with green growth by taking different steps. The bank adopts lean resource consumption practices across operations, to reduce their use of paper, energy and non-biodegradable material. ${ }^{13}$ In addition, they have automated covering approval system - An online system for approval of facilities which reduces consumption of paper and a new trilingual "email indemnity" has been executed to cover all communications by the bank via e-mail with the aim of reducing the usage of paper. The bank aids green enterprises, through special incentives, grants, loans and guidance and follows a separate green lending scheme.

\section{Challenges of green banking in Sri Lanka}

Credit risk is one of the major challenges for adopting green banking concept in Sri Lanka. Credit risk on finance will arise due to lending to those borrowers whose businesses are affected by the cost of pollution, change in environmental laws and regulations. Moreover, the possibility of customers' default is high due to the result of unexpected overheads for the capital investment in production facilities, third party claims and also the loss of market share due to such cases. Still, banking companies are in doubt on green financing activities. Apart from credit risk, stakeholders' awareness and support also a major challenge in the green banking performance (Anh, 2017). In Sri Lankan context also it is a big challenge. Normally, banks introduce new facilities with technology to reduce their paperwork and reduce the environment emission. However, in practice, limited numbers of customers they really have appropriate awareness and the limited number of them are supporting. Because of that the banking sector fails to enhance the desired outcome through ecological banking practices. Moreover, talented as well as wellexperienced human capital is required to provide proper service to customers through green banking practices. As a developing nation, still we are lacking on knowledge to design and promote Green Banking products to customers. In Sri Lanka, many banks in green business are quite new and are in the initial phase. Thus, it needs few years for banks to get back the money as their return on investment and it does not help banks during economic recessions and it causes to discourage the banking sector on green bank adaptations.

\section{Government responsibility in promoting green banking in Sri Lanka}

In Sri Lankan banking industry still there is a huge abridge on green banking policy. Therefore, as a responsible authority to general public government has a prime responsibility to develop a policy framework 
to green banking and publicize that policy. Moreover, the government has to place a complete set of laws and regulations on green banking.

However, without a policy most of state owned and private commercial banks have already taken some initiatives for green banking. Then, government has to monitor the progress of those initiatives regularly with analyzing industry trends and new developments. Moreover, public awareness on green bank practices and its impact on all stakeholders and economy are needed to achieve desired outcomes from green banking practices. It is vital important the, government to conduct awareness programmes to improve knowledge of banks and the other stakeholders. The government should encourage banks to adopt green banking practices by providing infrastructure facilities.

\section{Conclusion}

In twenty first century, the banking sector in developing countries has taken several steps to change their operating system in the past and the sector is getting restructured with new facilities such as internet banking, mobile banking, cash deposit machines etc. are replaced at the place of conventional banking systems. It appears that newly adopted banking methods are beneficial to all stakeholders of the banking system and economy and the green environment. More importantly, now a days, banks aware on their role in green growth and its importance to enhance sustainable economic growth in the developing nations. However, the Sri Lankan banking sector is still functioning at the primary stage green banking initiatives. However, the time demands a focus on the initiatives such as making awareness among society on green banking, and helping all small, medium and larger scale firms to change their conventional process to green oriented processes because it can be more ecologically friendly in nature and ultimately, it will also pervasive the concept of environmental sustainability. In future, researches have to think about whether the current green banking initiatives used by Sri Lankan banks are actually contributing to the sustainable growth or not. It is also learnt that global dialogs on green concepts has a significant orientation for the banks to go for green banking initiatives.

\section{Reference}

Anh, T.V. (2017). Impact of stakeholders on the performance of green banking products and services: The case of Vietnamese banks. Economic Annals, XXI, 143-151

Deka, G. (2015). Green Banking Practices: A Study on environmental strategies of banks with special reference to State bank of India. Indian Journal of Commerce and Management Studies, 6(3), 11.

Du, J. (2011). An empirical analysis of Internet banking adoption in New Zealand (PhD Thesis). Lincoln University. 
Ginovsky, J. (2009). Green bankingInside and out. Community Banker, 1(1), 30-32.

Hart, S. L., \& Ahuja, G. (1996). Does it pay to be green? An empirical examination of the relationship between emission reduction and firm performance. Business Strategy and Environment, 5, 30-37.

Heim, G., \& Zenklusen, O. (2005). Sustainable finance: Strategy options for development financing institutions. Eco: Fact, Stampfenbachstrass, Zurich.

Jayadatta, S., \& Nitin, S. N. (2017). Opportunities, Challenges, Initiatives and Avenues for Green Banking In India. International Journal of Business and Management Invention, 6(2), 10-15. Katyal, S., \& Nagpal, S. (2014). Role of Green Banking in Sustainable Development of India. International Journal of $360 \mathrm{o}$ Management Review, 2(1), 1-11.
Ragupathi, M., \& Sujatha, S. (2015). Green banking initiatives of commercial banks in India. International Research Journal of Business and Management, 8, 74-81.

Rajesh, T., \& Dileep, A. S. (2014). Role of banks in sustainable economic development through green banking. International Journal of Current Research and Academic Review, ISSN, 2347-3215.

Shaumya, K., \& Arulrajah, A. A. (2017). The Impact of Green Banking Practices on Bank's Environmental Performance: Evidence from Sri Lanka. Journal of Finance and Bank Management, 5(1), 77-90.

Sreesha, C. H. (2014). A Study of Green Banking Initiatives of Selected Private and Public Sector Banks in India. International Journal of Research (IJR), 1(7), 807-815.

Thombre, K. A. (2011). The new face of banking: Green banking. Research Paper-Commerce, 1(2), 1-4 
Foot Notes:

1. Sustainable Banking Network (SBN), Briefing Note - February 2017, International Finance Organization, World Bank Group

2. Asian Development Bank Institute, No 814.

3. The world council for sustainable development.

4. EMcompass, IMF, December 2016.

5

http://www.cbrc.gov.cn/chinese/files/20 18/DD114DBE72084577BBB4392A38 E65FFE.pdf.

6

https://www.dbj.jp/en/ir/about/system.h tml
7. FNG (2016).

8. Sri Lanka Banks' Association.

9. Annual Report, Bank of Ceylon, 2017.

10. Silva, U. (2016). Green banking initiatives in Sri Lanka with special reference to Commercial Bank of Ceylon PLC, National Conference on Green Practices.

11. Commercial Bank of Ceylon PLC. Bank Annual Report, Commercial Bank of Ceylon PLC: Sri Lanka. 2013 ,2014, 2015 and 2016.

12. https://www.hnb.net/mediacenter?nid=138. 